\title{
Population density estimates and conservation concern for clouded leopards Neofelis nebulosa, marbled cats Pardofelis marmorata and tigers Panthera tigris in Htamanthi Wildlife Sanctuary, Sagaing, Myanmar
}

\author{
Hea Naing, Joanna Ross, Dawn Burnham \\ SAW HTUn and David W. MaCDONALD
}

\begin{abstract}
The clouded leopard Neofelis nebulosa is a potent ambassador species for conservation, occurring from the Himalayan foothills eastwards to Indochina, between which Myanmar is a biogeographical land bridge. In Myanmar's Northern Forest Complex, the species co-occurs with the tiger Panthera tigris, leopard Panthera pardus, marbled cat Pardofelis marmorata, golden cat Catopuma temminckii and leopard cat Prionailurus bengalensis. We deployed cameras within the Htamanthi Wildlife Sanctuary over 2 consecutive years. In 2014-2015 we deployed 82 camera stations around the Nam Pa Gon stream (Catchment 1) for 7,365 trap days. In 2015-2016 we deployed 80 camera stations around the Nam E Zu stream (Catchment 2) for 7,192 trap days. In Catchment 1 we identified five tigers from 26 detections, five clouded leopards from 41 detections (68 photographs) and 11 marbled cats from 13 detections. Using Bayesian-based spatial capture-recapture we estimated the densities of tigers and clouded leopards to be $0.81 \pm$ SD 0.40 and $0.60 \pm$ SD 0.24 individuals per $100 \mathrm{~km}^{2}$, respectively. In Catchment 2 we identified two tigers from three detections, nine clouded leopards from 55 detections and 12 marbled cats from 37 detections. Densities of clouded leopards and marbled cats were $3.05 \pm$ SD 1.03 and $8.80 \pm$ SD 2.06 individuals per $100 \mathrm{~km}^{2}$, respectively. These differences suggest that human activities, in particular gold mining, are affecting felid populations, and these are a paramount concern in Htamanthi. We demonstrate the importance of Htamanthi within the Northern Forest Complex and highlight the Yawbawmee corridor as a candidate for protection.
\end{abstract}

Hla NAING* and SAW Htun Wildlife Conservation Society Myanmar, Yangon, Myanmar

Joanna Ross, Dawn Burnham and David W. Macdonald (Corresponding author) Wildlife Conservation Research Unit, Department of Zoology, University of Oxford, The Recanati-Kaplan Centre, Tubney House, Tubney, OX13 5QL, UK. E-mail david.macdonald@zoo.ox.ac.uk

${ }^{*}$ Also at: Wildlife Conservation Research Unit, Department of Zoology, University of Oxford, The Recanati-Kaplan Centre, Tubney, UK

Received 16 May 2016. Revision requested 21 September 2016.

Accepted 4 August 2017. First published online 27 November 2017.
Keywords Ambassador species, camera trapping, clouded leopard Neofelis nebulosa, density estimate, marbled cat Pardofelis marmorata, spatial capture-recapture, tiger Panthera tigris

\section{Introduction}

4 guild of wild species of Felidae comprising various A combinations of up to eight species (Macdonald et al., 2010) is distributed across South-east Asia, with species ranging in size from the tiger Panthera tigris to the flat-headed cat Prionailurus planiceps. Little is known of the ecology of most of these species, and less of their guilds. Amongst the least known is the clouded leopard Neofelis nebulosa, a potent ambassador species for conservation (Macdonald et al., unpubl. data) that occurs from the Himalayan foothills and eastwards to Indochina, between which Myanmar serves as a biogeographical land bridge. The species occupies areas undergoing some of the most rapid deforestation (Hansen et al., 2013), and is threatened by poaching and wildlife trafficking (D'Cruze \& Macdonald, 2015; Nijman \& Shepherd, 2015; Min et al., in press). Clouded leopards are the apex predators in many South-east Asian rainforests, although where they co-occur with larger predators such as tigers their density and habitat use may vary (Sunquist \& Sunquist, 2002; Sunarto et al., 2015). Although there have been discoveries regarding the felid guilds and habitat use of the Sunda clouded leopard Neofelis diardi (Haidir et al., 2013; Sollmann et al., 2014; Hearn et al., 2017; Macdonald et al., unpubl. data), and the threat to the species from habitat loss (Cushman et al., 2017), little is known for the mainland clouded leopard and the felids with which it is sympatric.

In Myanmar the density of clouded leopards has not been estimated; however, of the 17 areas of the country surveyed (by camera trapping) for tigers during 1999-2002, clouded leopards were found in 10 areas and tigers in three (Myanmar Forest Department, 2003). In 2004 clouded leopards were recorded in three mountainous regions of northern Myanmar where they had not been recorded previously (Zaw et al., 2014), and at a fourth site in the south 


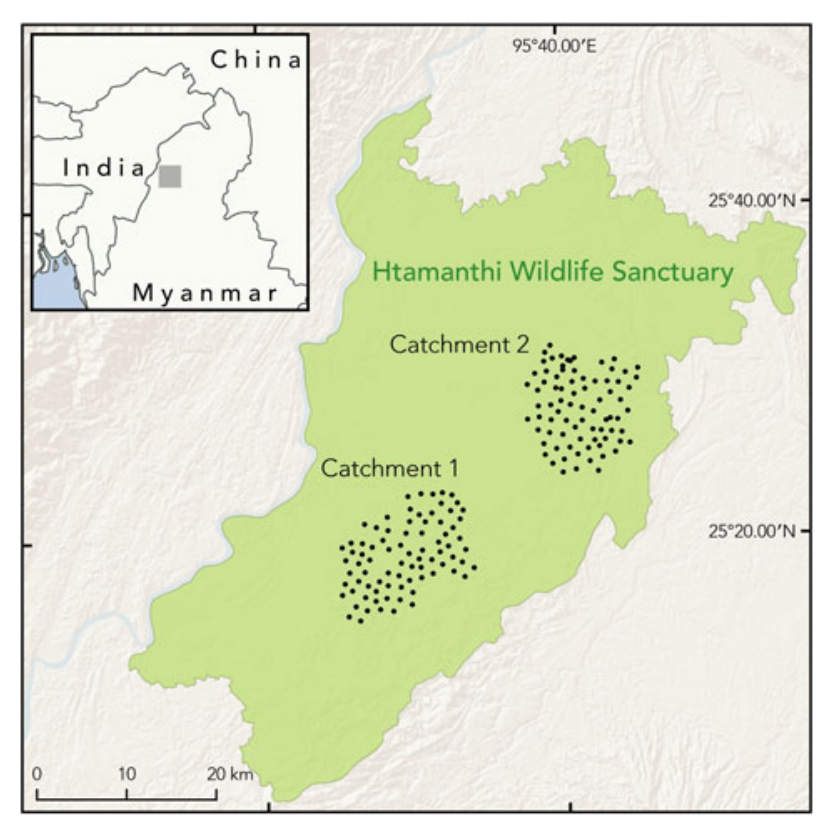

FIG. 1 Locations of camera traps in Catchments 1 and 2 of Htamanthi Wildlife Sanctuary, in north-western Myanmar.

(WCS, 2015, unpubl. data). Clouded leopards have also been confirmed in several locations in the east of the country (Moo et al., 2017). Among the northern sites, Htamanthi Wildlife Sanctuary is particularly important because of its proximity to the Northern Forest Complex. This vast contiguous forest landscape $\left(93,685 \mathrm{~km}^{2}\right)$, probably the largest in Asia, lies in a transition zone of three biodiversity hotspots, all of which contain clouded leopards and tigers: Himalaya, Indo-Burma and the Mountains of Southwest China (Myers et al., 2000; Conservation International, 2011).

As part of a range-wide camera-trapping study of the clouded leopard and members of its guild we deployed camera traps in two catchments within the Htamanthi Wildlife Sanctuary over 2 consecutive years. Htamanthi Wildlife Sanctuary is the southernmost Key Biodiversity Area of the Northern Forest Complex (also Tiger Conservation Landscape 37, GTRP, 2010).

\section{Study area}

Htamanthi Wildlife Sanctuary $\left(2,151 \mathrm{~km}^{2}\right)$ is one of the largest protected areas in the region, located between the Chindwin and Uru Rivers in north-western Myanmar (Fig. 1). The area is characterized by tropical evergreen forest, with some mixed deciduous forest in the western portion and dry mixed deciduous forest types along the eastern boundary (Arino et al., 2012). The area was gazetted for its megafauna, including the Asian elephant Elephas maximus, tiger, gaur Bos gaurus, Asiatic black bear Ursus thibetanus, sun bear Helarctos malayanus and clouded leopard. Seven streams flow in parallel from the eastern and north-eastern hills to the western and south-western part of the Sanctuary, and most from the eastern side can be navigated by boat throughout the year, except for their upper reaches in the driest parts of summer. There are three main footpaths connecting villages on the west and east sides of the Sanctuary. There are four management zones, Nam Phi Lin, Nam E Zu, Nam Pa Gon and Nam Yan Yin; this study was conducted in an area of $149 \mathrm{~km}^{2}$ in Nam Pa Gon and of $136 \mathrm{~km}^{2}$ in Nam E Zu.

\section{Methods}

\section{Camera trapping}

We used two models of passive infrared digital camera traps (Cuddeback, Non Typical Inc., De Pere, USA, and ScoutGuard, HCO Outdoor Products, Norcross, USA). During 1 December 2014-13 March 2015 we deployed 82 camera stations in Catchment 1, Nam Pa Gon, with 1.0-1.5 km between camera stations. During 3 December 2015-23 March 2016 we deployed 80 camera stations in Catchment 2, Nam E Zu, with similar spacing. At each station we used unbaited, paired camera traps, set at c. $45 \mathrm{~cm}$ height from ground level and c. $3.5 \mathrm{~m}$ either side of the trail.

\section{Analysis}

We estimated population densities of tigers, clouded leopards and marbled cats, using a spatially explicit capture-recapture model implemented within a Bayesian framework using the package SPACECAP v. 1.1.o (Gopalaswamy et al., 2012) in $R v 3.3 .1$ (R Development Core Team, 2016). Individual identification was carried out by at least two people, and detection histories for each individual were then constructed. We considered each 24-hour period to be a sampling occasion, as short sampling intervals can improve the precision of estimates in spatially explicit capture-recapture analyses (Goldberg et al., 2015). To assume we were surveying a demographically closed population we used a 90-day survey period for tigers and clouded leopards. Marbled cats are smaller and therefore may have a higher population turnover, so we subsampled a 6o-day period that maximized detections for marbled cats. For clouded leopards we explored the consequences of adopting a 6o-day period, again subsampled to maximize detections. These are similar or shorter durations compared with other estimates of population density, justifying the assumed sampling of a closed population (e.g. Brodie \& Giordano, 2012; Wilting et al., 2012; Mohamed et al., 2013; Hearn et al., 2016). We constructed the state space by adding a buffer to the coordinates of the outermost camera stations, using ArcMap 10.3 (ESRI, Redlands, USA). We then added potential activity centres by generating regularly spaced points with a resolution of $0.25 \mathrm{~km}^{2}$ (tigers and clouded 
leopards) or $0.16 \mathrm{~km}^{2}$ (marbled cats) within this buffer. Each activity centre was designated either habitat or non-habitat, based on local knowledge of the area. As land outside the boundaries of the park is largely agricultural and human presence is high, we designated all activity centre points falling outside the park as non-habitat. We increased the size of the state space during preliminary analyses until the probability of detection at the edge of the state space became negligible. We determined that a buffer of $20 \mathrm{~km}$ was sufficient for clouded leopards and tigers, and a buffer of $12 \mathrm{~km}$ was appropriate for marbled cats. For all analyses we ran SPACECAP with trap response absent, half normal detection function, 100,000 iterations and a thinning rate of 1. In SPACECAP parameter convergence is assessed using Geweke $z$ scores; values between -1.64 and 1.64 are considered to be acceptable. We increased the burn-in (the number of initial iterations discarded during the analysis) during preliminary runs until the Geweke $z$ scores fell within this range. The upper limit to the population size within the state space is set by the data augmentation value. We increased this value until $\psi$ (the ratio of the estimated abundance within the state space to the maximum defined by the data augmentation value) was $\leq$ o.8. For Catchment 1 we ran the clouded leopard data with a burn-in of 10,000 for the 90-day peirod and 30,000 for the 60 day period. The tiger data were run with a burn-in of 20,000 . The data augmentation value was set to 60 for both species. For Catchment 2 we ran the clouded leopard data with a burn-in of 30,000 and data augmentation of 150 for both the 90- and 6o-day periods. The marbled cat data were run with a burn-in of 30,000 and data augmentation of 210. We compared clouded leopard densities between catchments, and following Sollmann et al. (2014) we considered a difference to be significant if the $95 \%$ highest posterior density of one did not include the mean of the other.

As Asiatic golden cats do not have patterned coats they are not reliably identifiable to individual, and therefore population densities cannot be estimated using these methods. For golden cats, leopard cats and potential felid prey detected by the cameras we calculated the number of independent detections and naïve occupancy, which was calculated as the proportion of camera stations at which the species was detected.

\section{Results}

We detected all three focal species in both catchments, but detection frequencies and naïve occupancies varied greatly (Tables 1 \& 2). In Catchment 1 we were able to identify $100 \%$ of the tiger photographs, $83.8 \%$ of clouded leopard photographs and $91.7 \%$ of marbled cat photographs to individual. Given the limited number of re-detections of

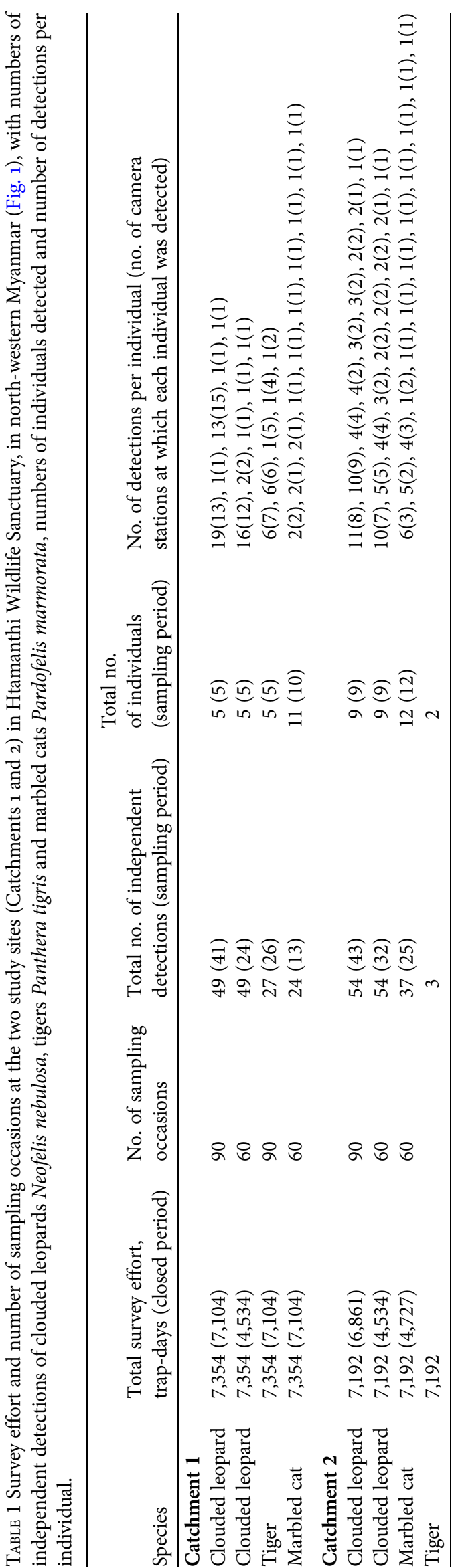


TABLE 2 The total number of independent detections, detection rate, and naïve occupancies for felid species and potential prey species of tigers and clouded leopards at the two study sites (Catchments 1 and 2) in Htamanthi Wildlife Sanctuary, in north-western Myanmar (Fig. 1).

\begin{tabular}{|c|c|c|c|c|}
\hline \multirow[b]{2}{*}{ Species } & \multicolumn{2}{|c|}{$\begin{array}{l}\text { Total no. of independent detections } \\
\text { (detection rate } \text { rat }^{\star}\end{array}$} & \multicolumn{2}{|c|}{ Naïve occupancy } \\
\hline & $\begin{array}{l}\text { Catchment } 1 \\
(7,354 \text { trap days })\end{array}$ & $\begin{array}{l}\text { Catchment } 2 \\
(7,192 \text { trap days })\end{array}$ & Catchment 1 & Catchment 2 \\
\hline Tiger & $27(0.37)$ & $3(0.04)$ & 0.23 & 0.04 \\
\hline Clouded leopard & $49(0.67)$ & $54(0.75)$ & 0.44 & 0.39 \\
\hline Asiatic golden cat Catopuma temminckii & $104(1.41)$ & $62(0.86)$ & 0.41 & 0.28 \\
\hline Marbled cat & $24(0.33)$ & $37(0.51)$ & 0.16 & 0.23 \\
\hline Leopard cat Prionailurus bengalensis & $75(1.02)$ & $84(1.17)$ & 0.26 & 0.3 \\
\hline Leopard Panthera pardus & $0(0)$ & $1(0.01)$ & 0 & 0.01 \\
\hline Gaur Bos gaurus & $67(0.91)$ & $12(0.17)$ & 0.34 & 0.15 \\
\hline Wild boar Sus scrofa & $141(1.92)$ & $122(1.70)$ & 0.61 & 0.56 \\
\hline Northern red muntjac Muntiacus vaginalis & $563(7.66)$ & $491(6.83)$ & 0.94 & 0.85 \\
\hline Sambar deer Rusa unicolor & $0(0)$ & $1(0.01)$ & 0 & 0.01 \\
\hline Chinese serow Capricornis milneedwardsii & $2(0.03)$ & $0(0)$ & 0.02 & 0 \\
\hline Malayan porcupine Hystrix brachyura & $121(1.65)$ & $138(1.92)$ & 0.30 & 0.45 \\
\hline Stump-tailed macaque Macaca arctoides & $35(0.48)$ & $43(0.60)$ & 0.34 & 0.33 \\
\hline Northern pig-tailed macaque Macaca leonina & $11(0.15)$ & $12(0.17)$ & 0.11 & 0.14 \\
\hline
\end{tabular}

${ }^{*}$ The number of independent detections per 100 trap days

marbled cats it was not possible to model these data, and the values are included for comparison only.

The spatially explicit capture-recapture posterior summaries of the model parameter values are in Table 3. The Bayesian p-values indicated that the models were of adequate fit, and the Geweke $z$ scores indicated that all model parameters converged. The estimated density for clouded leopards in Catchment 1 derived from the 90-day period is $0.60 \pm S D 0.24$ individuals per $100 \mathrm{~km}^{2}$ and from the 60 -day period $0.62 \pm S D 0.24$ individuals per $100 \mathrm{~km}^{2}$. For tigers the density estimate is $0.81 \pm \mathrm{SD} 0.40$ individuals per $100 \mathrm{~km}^{2}$.

In Catchment 2 we were able to identify $100 \%$ of the tiger photographs, $79 \%$ of clouded leopard photographs and $72 \%$ of marbled cat photographs to individual. The clouded leopard population density was significantly higher than in Catchment 1, with estimates of $3.05 \pm$ SD 1.03 and $3.15 \pm$ SD 1.13 individuals per $100 \mathrm{~km}^{2}$ from the $90-$ and 6o-day periods, respectively. The population density of marbled cats was $8.75 \pm \mathrm{SD} 2.6$ individuals per $100 \mathrm{~km}^{2}$. There were too few tiger detections to estimate population density (Table 3 ).

\section{Discussion}

We present the first population density estimates for the clouded leopard and marbled cat in Myanmar. We found that 60- and 90-day periods for clouded leopards yielded almost identical results, and we are confident that surveying for 90 days is appropriate to assume the population is closed.

\section{Numbers and population densities of tigers}

Given the substantial difference in tiger numbers detected between the surveys of Catchments 1 and 2, although only a year apart and separated by $<20 \mathrm{~km}$, it is not useful to calculate a mean from the aggregated data. However, had we extrapolated from the estimated population density in Catchment 1 this would have yielded an estimate of 16 tigers (range 10-30 tigers) in the Htamanthi Wildlife Sanctuary, similar to the estimate of 15 by Rabinowitz et al. (1995) and within the wide range of densities (0.2-2.2 tigers per $100 \mathrm{~km}^{2}$ ) estimated in the Hukaung Valley (Lynam et al., 2009). Such an extrapolation might have seemed warranted in the light of observations of field signs and prey, and the relative abundance of the tiger's preferred prey, the Eurasian wild pig Sus scrofa, the gaur and the barking deer Muntiacus vaginalis (Hayward et al., 2012; Ngoprasert et al., 2012). During January 2013-January 2014 the Wildlife Conservation Society's biological monitoring team (monitoring the eastern hoolock gibbon Hoolock leuconedys), SMART (Spatial Monitoring and Reporting Tool) patrol teams and a community-based natural resource management team confirmed that tigers were present from the southern buffer zone to the northern boundary of the Sanctuary $(60-80 \mathrm{~km})$. However, the results from Catchment 2 suggest that the tiger population density may be significantly lower than in Catchment 1 , and we consider possible explanations for this below. Our estimates of tiger population densities are presented in the context of methodologically comparable estimates elsewhere in South-east Asia in Table 4. 


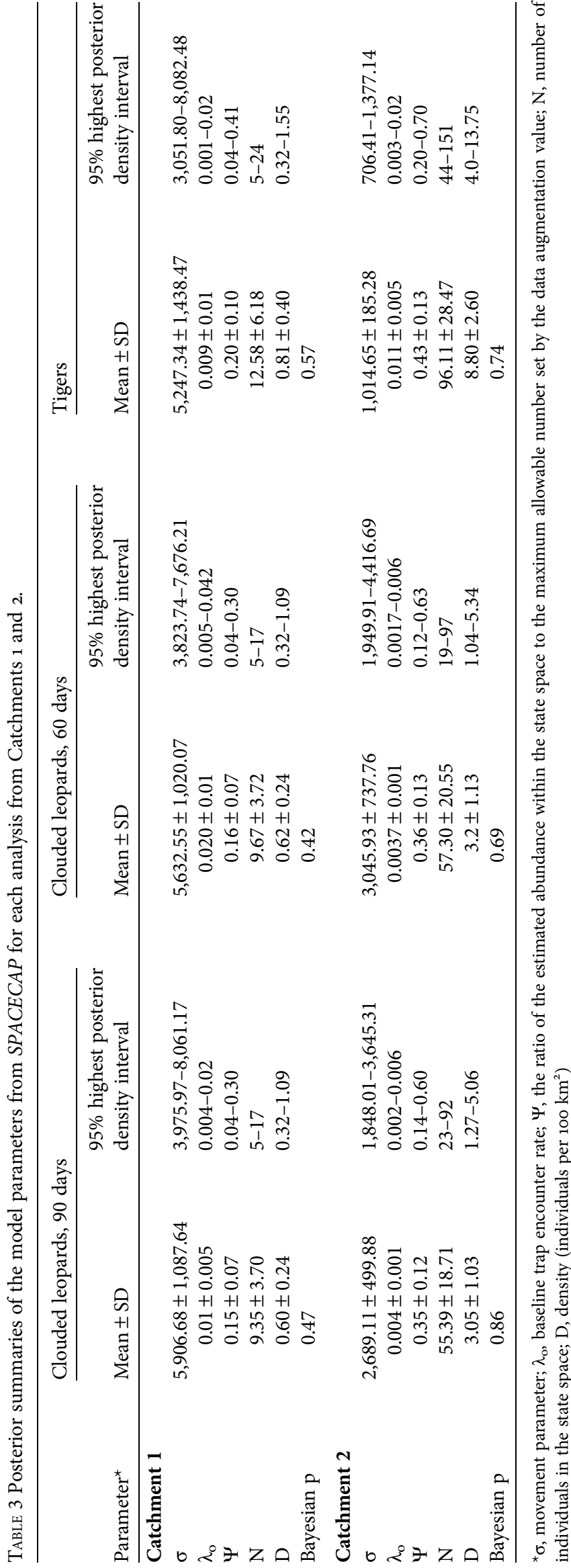

\section{Abundance and population densities of clouded leopards}

With no previous data on clouded leopard numbers in the Sanctuary we cannot assess whether their abundance has changed, but we present our data for comparison with methodologically comparable studies for other populations of N. nebulosa and N. diardi in Table 5.

Population density of marbled cats, and naïve occupancy of other felids and potential prey

Marbled cats are little studied and there are only two other estimates for comparison. Hearn et al. (2016) found densities of 7.1-19.57 individuals per $100 \mathrm{~km}^{2}$, depending on study area, and Singh \& Macdonald (2017) report densities of 5.03 individuals per $100 \mathrm{~km}^{2}$. Our results are in line with these estimates. Our naïve occupancy estimates for felids are comparable to those reported in previous studies; for example, Haidir et al. (2013) found that the naïve occupancy of golden cats in Sumatra was 0.42, and for Sunda clouded leopards was 0.38 . The occupancy of ungulates has been little studied in South-east Asia, but Gray \& Prum (2012) reported a naïve occupancy of 0.16 for gaur in Cambodia. This is similar to our result of 0.15 in Catchment 2. Gray (2012) also reported that tiger abundance was also very low in the same area of Cambodia, which suggests that low numbers of gaur may be limiting tiger populations in these areas.

\section{Guild compositions and explanations for differences between Catchments 1 and 2}

Felid species and other mammalian carnivores occur throughout South-east Asia in various combinations. These guilds offer the opportunity to study the ecological processes of guild dynamics and, specifically, potential competition between the member species. A plausible hypothesis for wild felids, and one for which there is strong evidence amongst the Canidae (Macdonald \& Sillero-Zubiri, 2004), is that competition from larger species of felids will be inimical to somewhat smaller species within a guild, and that this in turn could result in mesopredator release for yet smaller species. This does not appear to be the case on Sumatra, where the Sunda clouded leopard co-occurs with tigers. Density estimates from Sumatra (Sollmann et al., 2014) and Borneo (Brodie \& Giordano, 2012; Wilting et al., 2012; Hearn et al., 2017) are broadly similar, suggesting that tigers are not a limiting factor for clouded leopards on Sumatra.

Our comparison of Catchments 1 and 2 provides the opportunity to evaluate the number of clouded leopards where tigers were relatively abundant and where they 
TABLE 4 Published estimates of tiger population density based on the use of spatially explicit techniques.

\begin{tabular}{|c|c|c|c|c|}
\hline Site & $\begin{array}{l}\text { Density } \\
\text { (individuals } \\
\text { per } 100 \mathrm{~km}^{2} \text { ) }\end{array}$ & $\begin{array}{l}95 \% \mathrm{CI} / \text { highest } \\
\text { posterior density } \\
\text { interval }\end{array}$ & $\begin{array}{l}\text { Spatially explicit } \\
\text { capture-recapture } \\
\text { method }\end{array}$ & Source \\
\hline Ussuriiskii Nature Reserve, Russia & $0.112-0.586$ & * & Bayesian & $\begin{array}{l}\text { Hernandez-Blanco } \\
\text { et al. (2013) }\end{array}$ \\
\hline \multirow[t]{4}{*}{ Rajaji National Park, India } & $3.31 \pm \mathrm{SD} 1.51$ & $1.56-7.03$ & Bayesian & \multirow[t]{4}{*}{ Harihar et al. (2011) } \\
\hline & $2.67 \pm$ SD 0.97 & $1.24-4.96$ & Bayesian & \\
\hline & $5.17 \pm$ SD 1.94 & $2.07-9.50$ & Bayesian & \\
\hline & $5.81 \pm \operatorname{SD} 2.26$ & $1.86-9.92$ & Bayesian & \\
\hline Mudumalai Tiger Reserve, India & $8.31 \pm$ SE 2.56 & * & Bayesian & Kalle et al. (2011) \\
\hline Ranthambhore Tiger Reserve, India & $6.1 \pm \operatorname{SE} 1.2$ & * & Maximum likelihood & Singh et al. (2014b) \\
\hline \multirow{2}{*}{ Kalakad-Mundanthurai Tiger Reserve, India } & $2.9 \pm$ SE 1.40 & * & Bayesian & \multirow[t]{2}{*}{ Ramesh et al. (2012) } \\
\hline & $2.2 \pm$ SE 1.6 & * & Maximum likelihood & \\
\hline Pakke Tiger Reserve, India & $1.86 \pm$ SE 0.7 & * & Maximum likelihood & Selvan et al. (2014) \\
\hline \multirow[t]{4}{*}{ Hunchun National Nature Reserve } & $0.33 \pm$ SD 0.10 & $0.18-0.56$ & Bayesian & \multirow[t]{4}{*}{ Xiao et al. (2016) } \\
\hline & $0.40 \pm$ SD 0.12 & $0.20-0.68$ & Bayesian & \\
\hline & $0.30 \pm$ SE 0.10 & $0.16-0.55$ & Maximum likelihood & \\
\hline & $0.24 \pm$ SE 0.09 & $0.12-0.48$ & Maximum likelihood & \\
\hline \multirow[t]{2}{*}{ Sundarbans, India } & $4.08 \pm$ SE 1.51 & $0.18-0.56$ & Maximum likelihood & \multirow[t]{2}{*}{ Roy et al. (2016) } \\
\hline & $5.81 \pm$ SE 1.24 & & Maximum likelihood & \\
\hline Suklaphanta Wildlife Reserve, Nepal & $2.10 \pm$ SE 0.8 & * & Maximum likelihood & Karki (2011) \\
\hline \multirow[t]{2}{*}{ Chitwan National Park, Nepal } & $2.21 \pm \operatorname{SD} 0.42$ & $1.41-3.01$ & Bayesian & Thapa \& Kelly (2017) \\
\hline & $2.08 \pm \mathrm{SD} 1.13$ & $0.31-4.39$ & Bayesian & Thapa \& Kelly (2017) \\
\hline Pakke Tiger Reserve, India & $0.97 \pm$ SE 0.23 & * & Maximum likelihood & Singh et al. (2014a) \\
\hline
\end{tabular}

*Data are not available.

TABLE 5 Published estimates of clouded leopard population density based on the use of spatially explicit techniques.

\begin{tabular}{|c|c|c|c|c|}
\hline Site & $\begin{array}{l}\text { Density } \\
\text { (individuals per } \\
100 \mathrm{~km}^{2} \text { ) }\end{array}$ & $\begin{array}{l}\text { 95\% CI/highest } \\
\text { posterior density } \\
\text { interval }\end{array}$ & $\begin{array}{l}\text { Spatially explicit } \\
\text { capture-recapture } \\
\text { method }\end{array}$ & Source \\
\hline \multicolumn{5}{|l|}{ Sunda clouded leopard Neofelis diardi } \\
\hline $\begin{array}{l}\text { Tangkulap-Pinangah Forest Reserve, Sabah, } \\
\text { Malaysia }\end{array}$ & $0.84 \pm$ SD 0.42 & $0.25-1.83$ & Bayesian & Wilting et al. (2012) \\
\hline $\begin{array}{l}\text { Segaliud Lokan Forest Reserve, Sabah, } \\
\text { Malaysia }\end{array}$ & $1.04 \pm$ SD 0.58 & $0.29-2.55$ & Bayesian & Wilting et al. (2012) \\
\hline $\begin{array}{l}\text { Maliau Basin Conservation Area, Sabah, } \\
\text { Malaysia }\end{array}$ & $1.90 \pm \mathrm{SE}^{\star}$ & $0.70-5.40$ & $\begin{array}{l}\text { Maximum } \\
\text { likelihood }\end{array}$ & Brodie \& Giordano (2012) \\
\hline Renah Kayu Embun, Sumatra, Indonesia & $1.57 \pm$ SD 0.69 & $0.58-3.27$ & Bayesian & Sollmann et al. (2014) \\
\hline Sipurak, Sumatra, Indonesia & $0.77 \pm$ SD 0.52 & $0.15-2.10$ & Bayesian & Sollmann et al. (2014) \\
\hline Bungo, Sumatra, Indonesia & $1.62 \pm$ SD 0.73 & $0.58-3.37$ & Bayesian & Sollmann et al. (2014) \\
\hline Ipuh, Sumatra, Indonesia & $1.11 \pm \mathrm{SD} 0.47$ & $0.42-2.24$ & Bayesian & Sollmann et al. (2014) \\
\hline $\begin{array}{l}\text { Danum Valley Conservation Area, Sabah, } \\
\text { Malaysia }\end{array}$ & $1.73 \pm$ SD 0.54 & $0.81-2.78$ & Bayesian & Hearn et al. (2017) \\
\hline Tawau Hills Park, Sabah, Malaysia & $2.23 \pm$ SD 0.52 & $1.35-3.27$ & Bayesian & Hearn et al. (2017) \\
\hline Crocker Range Park, Sabah, Malaysia & $1.39 \pm$ SD 0.41 & $0.77-2.21$ & Bayesian & Hearn et al. (2017) \\
\hline Ulu Segama Forest Reserve, Sabah, Malaysia & $3.10 \pm$ SD 1.11 & $1.26-5.32$ & Bayesian & Hearn et al. (2017) \\
\hline Tabin Wildlife Sanctuary, Sabah, Malaysia & $2.66 \pm$ SD 1.11 & $0.79-4.74$ & Bayesian & Hearn et al. (2017) \\
\hline $\begin{array}{l}\text { Kinabatangan Wildlife Sanctuary, Sabah, } \\
\text { Malaysia }\end{array}$ & $1.54 \pm \mathrm{SD} 0.70$ & $0.41-2.90$ & Bayesian & Hearn et al. (2017) \\
\hline \multicolumn{5}{|l|}{$\begin{array}{l}\text { Mainland clouded leopard Neofelis } \\
\text { nebulosa }\end{array}$} \\
\hline Manas National Park, India & $4.73 \pm$ SE 1.43 & * & Maximum likelihood & Borah et al. (2014) \\
\hline Temengor, Malaysia & $3.46 \pm$ SE 1.00 & $1.98-6.04$ & Maximum likelihood & Mohamad et al. (2015) \\
\hline Belum, Malaysia & $1.83 \pm$ SE 0.61 & $0.97-3.48$ & Maximum likelihood & Mohamad et al. (2015) \\
\hline Dampa Wildlife Reserve, India & $5.14 \pm \mathrm{SD} 1.80$ & $2.05-8.72$ & Bayesian & Singh \& Macdonald (2017) \\
\hline
\end{tabular}

${ }^{\star}$ Data are not available. 


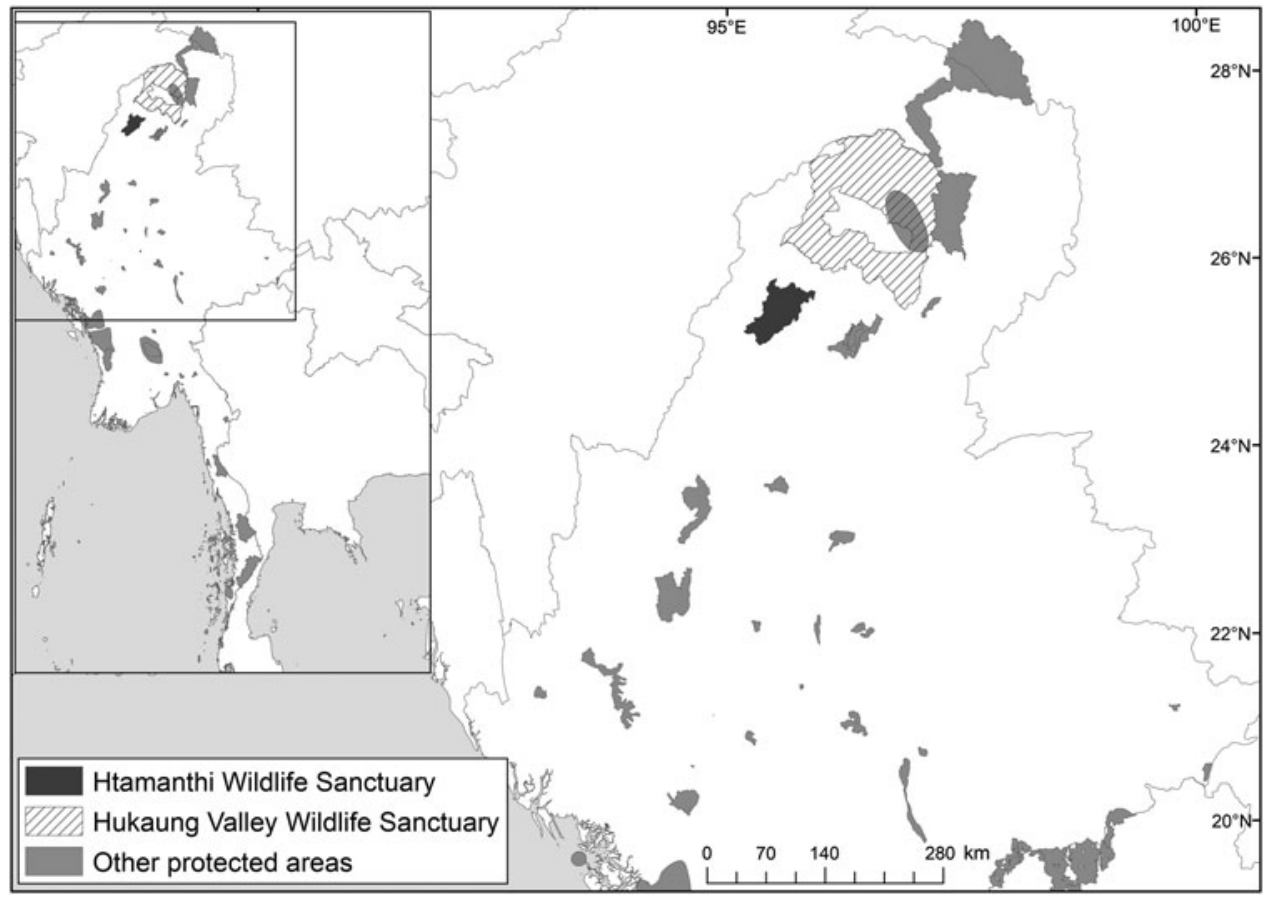

FIG. 2 Location of Htamanthi Wildlife Sanctuary in relation to Hukaung Valley Wildlife Sanctuary and other protected areas in the north of Myanmar. were less so. The difference in estimated population density of clouded leopards (o.6 individuals per $100 \mathrm{~km}^{2}$ in Catchment 1 compared to 3.05 individuals per $\mathrm{km}$ in Catchment 2) is in line with the prediction of the intra-guild hostility hypothesis.

These comparisons raise the question of why there were markedly fewer tigers in Catchment 2 than in Catchment 1 , and what other factors might underlie the different guild dynamics observed between these surveys. Three obvious, and not mutually exclusive, hypotheses are that (1) there was a difference in habitat or prey availability, or some other environmental variable, between the two sites, (2) conditions changed between the two survey periods, or (3) some other factor, such as an anthropogenic impact, caused the differences in felid guild structure, either directly or indirectly. Given that the two catchments are separated by $<20 \mathrm{~km}$ and seem generally similar, the habitat hypothesis is unpromising. However, two large prey species, gaur and serow Capricornis milneedwardsii, were detected less frequently in Catchment 2 (Table 2). The temporal change hypothesis is also unpromising, given that the two surveys were separated by barely 12 months. However, the third hypothesis, that Catchment 2 was subject to damaging human activity, is strongly supported. SMART patrols and incidental observations in 2013 indicated that although there were human incursions in both areas, incidents of gold mining were 14 times higher in Catchment 2 than in Catchment 1 , and $>80$ snares were removed from Catchment 2 compared with o in Catchment 1 for a similar patrol effort.
Human presence could influence the mammalian community structure in several ways. People may engender fear amongst both felids and their prey (e.g. Oriol-Cotterill et al., 2015a,b), and may affect tigers directly by killing them, and indirectly by killing their prey (the absence of gaur and serow may be a case in point and, being big prey, may affect the biggest felids); another possibility is that the domestic stock trafficked through the protected area could transmit disease to the wild ungulates.

The anthropogenic hypothesis is sufficiently compelling, and has such serious implications for conservation, that it merits further investigation as a priority. Rabinowitz et al. (1995) cautioned that the populations of tigers and gaur were at risk of elimination if threats prevailing at the time were not controlled, and we suspect this warning is now even more pressing.

\section{The Yawbawmee Corridor}

The National Tiger Survey (1999-2002) confirmed the presence of tigers in Hukaung Valley, Upper Chindwin, Htamanthi in northern Myanmar, and Tenasserim Hills in the south. Our findings emphasize the importance of Htamanthi within the northern Myanmar landscape. To the immediate north of Htamanthi lies the Yawbawmee Corridor, $3,213 \mathrm{~km}^{2}$ of currently unprotected forest, which could link Htamanthi with Hukaung Valley Wildlife Sanctuary (Fig. 2). The gazettement of this corridor would 
substantially increase the connectivity of the protected areas of the Northern Forest Complex and would deliver a substantial contribution to landscape-level conservation of felids and other threatened species in the region.

\section{Acknowledgements}

The survey was funded jointly by a grant to DWM from Partnership for Change and by Wildlife Conservation Society (WCS) Myanmar, with support and coordination from Htamanthi Wildlife Sanctuary, Nature Wildlife Conservation Division, Myanmar Forest Department. We thank Dr Nyi Nyi Kyaw, Director General of Myanmar Forest Department, and U Win Naing Thaw, Director of the Nature Wildlife Conservation Division under the Ministry of Natural Resources and Environmental Conservation, for granting permission and supporting the project; Htamanthi Park Warden U Khin Maung Hla and park rangers for logistical support to our field team; the survey team members for their tireless effort and dedication; WCS Myanmar Country Director U Than Myint, Northern Forest Complex Coordinator U Than Zaw and staff for support throughout the project; and Cedric Tan and two anonymous reviewers for their valuable inputs. DWM gratefully acknowledges grants from the DASSK Trust and the Irrawaddy Policy Exchange for the training of Myanmar conservationists and support of our clouded leopard programme. We thank the Recanati-Kaplan Foundation, Panthera and Robertson Foundation for their wider support of WildCRU.

\section{Author contributions}

DWM, DB and SH conceived the study. DWM, SH and HN designed the study and HN collected the data. JR and HN conducted data analysis. DWM, DB, JR, SH and HN wrote the article.

\section{References}

Arino, O., Ramos Perez, J.J., Kalogirou, V., Bontemps, S., Defourny, P. \& Van Bogaert, E. (2012) Global Land Cover Map for 2009 (GlobCover 2009). European Space Agency \& Université catholique de Louvain. Http://dx.doi.org/10.1594/PANGAEA. 787668 [accessed 7 September 2017].

Borah, J., Sharma, T., Das, D., Rabha, N., Kakati, N., Basumatary, A. et al. (2014) Abundance and density estimates for common leopard Panthera pardus and clouded leopard Neofelis nebulosa in Manas National Park, Assam, India. Oryx, 48, 149-155.

Brodie, J. \& Giordano, A.J. (2012) Density of the Vulnerable Sunda clouded leopard Neofelis diardi in a protected area in Sabah, Malaysian Borneo. Oryx, 46, 427-430.

Conservation International (2011) Biodiversity Hotspots Revisited. Conservation International, Washington, DC, USA. Http://www.biodiversityhotspots.org/xp/Hotspots/resources/maps. xml [accessed 18 October 2015].
Cushman, S.A., Macdonald, E.A., Landguth, E.L., Malhi, Y. \& Macdonald, D.W. (2017) Multiple-scale prediction of forest loss risk across Borneo. Landscape Ecology, 32, 1581-1598.

D'Cruze, N. \& Macdonald, D.W. (2015) Clouded in mystery: the global trade in clouded leopards. Biodiversity and Conservation, 24, 3505-3526.

GoldberG, J.F., Tempa, T., Norbu, N., Hebblewhite, M., Mills, L. S., WangchuK, T.R. \& Lukacs, P. (2015) Examining temporal sample scale and model choice with spatial capture-recapture models in the common leopard Panthera pardus. PLoS ONE, 10(11), e0140757.

Gopalaswamy, A.M., Royle, J.A., Hines, J.E., Singh, P., Jathanna, D., Kumar, N.S. \& Karanth, K.U. (2012) Program SPACECAP: software for estimating animal density using spatially explicit capture-recapture models. Methods in Ecology and Evolution, 3, 1067-1072.

Gray, T.N.E. \& PrUm, S. (2012) Leopard density in post-conflict landscape, Cambodia: evidence from spatially explicit capturerecapture. The Journal of Wildlife Management, 76, 163-169.

GTrP (Global Tiger Recovery Program) (2010) Global Tiger Recovery Program 2010-2022. Http://documents.worldbank.org/ curated/en/874191468331048098/pdf/732050WPooBox30110 FinaloVersionoEng.pdf [accessed 7 September 2017].

Haidir, I.A., Dinata, Y., Linkie, M. \& Macdonald, D.W. (2013) Asiatic golden cat and Sunda clouded leopard occupancy in the Kerinci Seblat landscape, West-Central Sumatra. Cat News, 59, 7-10.

Hansen, M.C., Potapov, P.V., Moore, R., Hancher, M., Turubanova, S.A., Tyukavina, A. et al. (2013) High-resolution global maps of 21st-century forest cover change. Science, 342, $850-853$.

Harihar, A., Pandav, B. \& Goyal, S.P. (2011) Responses of leopard Panthera pardus to the recovery of a tiger Panthera tigris population. Journal of Applied Ecology, 48, 806-814.

Hayward, M.W., Jędrzejewski, W. \& Jêdrzejewska, B. (2012) Prey preferences of the tiger Panthera tigris. Journal of Zoology, 286, 221-231.

Hearn, A.J., Ross, J., Bernard, H., Bakar, S.A., Goossens, B., Hunter, L.T.B. \& Macdonald, D.W. (2017) Responses of Sunda clouded leopard density to anthropogenic disturbance and refining estimates of their conservation status in Sabah. Oryx, https://doi. org/10.1017/So030605317001065.

Hearn, A.J., Ross, J., Bernard, H., Bakar, S.A., Hunter, L.T.B. \& Macdonald, D.W. (2016) The first estimates of marbled cat Pardofelis marmorata population density from Bornean primary and selectively logged forest. PLoS ONE, 11(3), e0151046.

Hernandez-Blanco, J.A., Rozhnov, V.V., Lukarevskiy, V.S., Naidenko, S.V., Chistopolova, M.D., Sorokin, P.A. et al. (2013) Spatially explicit capture-recapture method (SECR, SPACECAP): a new approach to determination of the Amur tiger (Panthera tigris altaica) population density by means of camera-traps. Doklady Biological Sciences, 453, 365-368.

Kalle, R., Ramesh, T., Qureshi, Q. \& Sankar, K. (2011) Density of tiger and leopard in a tropical deciduous forest of Mudumalai Tiger Reserve, southern India, as estimated using photographic capturerecapture sampling. Acta Theriologica, 56, 335-342.

KARKI, J.B. (2011) Occupancy and abundance of tigers and their prey in the Terai Arc Landscape, Nepal. PhD thesis. Forest Research Institute University, Dehradun, India.

Lynam, A.J., Rabinowitz, A., Myint, T., Maung, M., Latt, K.T. \& Po, S.H.T. (2009) Estimating abundance with sparse data: tigers in northern Myanmar. Population Ecology, 51, 115-121.

Macdonald, D.W. \& Sillero-Zubiri, C. (2004) Dramatis personae. In The Biology and Conservation of Wild Canids (eds 
D.W. Macdonald \& C. Sillero-Zubiri), pp. 3-36. Oxford University Press, Oxford, UK.

Macdonald, D.W., Loveridge, A.J. \& Nowell, K. (2010) Dramatis personae: an introduction to the wild felids. In The Biology and Conservation of Wild Felids (eds D.W. Macdonald \& A.J. Loveridge), pp. 3-58. Oxford University Press, Oxford, UK.

Min, S., D'Cruze, N. \& Macdonald, D.W. (in press) A note on felid trade at local markets in Myanmar. Cat News, 67.

Mohamad, S.W., Rayan, D.M., Christopher, W.C.T., Hamirul, M., Mohamed, A., Lau, C.F. \& Siwan, E.S. (2015) The first description of population density and habitat use of the mainland clouded leopard Neofelis nebulosa within a logged-primary forest in South East Asia. Population Ecology, 57, 495-503.

Mohamed, A., Sollmann, R., Bernard, H., Ambu, L.N., Lagan, P., Mannan, S. et al. (2013) Density and habitat use of the leopard cat (Prionailurus bengalensis) in three commercial forest reserves in Sabah, Malaysian Borneo. Journal of Mammalogy, 94, 82-89.

Moo, S.S.B., Froese, G.Z.L. \& Gray, T.N.E. (2017) First structured camera-trap surveys in Karen State, Myanmar, reveal high diversity of globally threatened mammals. Oryx, https://doi.org/10.1017/ Soo30605316001113.

Myanmar Forest Department (2003) A National Tiger Action Plan for the Union of Myanmar. Myanmar Forest Department, Ministry of Forestry, Yangon, Myanmar.

Myers, N., Mittermeier, R.A., Mittermeier, C.G., da Fonseca, G.A.B. \& Kent, J. (2000) Biodiversity hotspots for conservation priorities. Nature, 403, 853-858.

Ngoprasert, D., Lynam, A.J., Sukmasuang, R., Tantipisanuh, N., Chutipong, W., Steinmetz, R. et al. (2012) Occurrence of three felids across a network of protected areas in Thailand: prey, intraguild, and habitat associations. Biotropica, 44, 810-817.

Nijman, V. \& Shepherd, C.R. (2015) Trade in tigers and other wild cats in Mong La and Tachilek, Myanmar-a tale of two border towns. Biological Conservation, 182, 1-7.

Oriol-Cotterill, A., Macdonald, D.W., Valeix, M., Ekwanga, S. \& Frank, L.G. (2015a) Spatiotemporal patterns of lion space use in a human-dominated landscape. Animal Behaviour, 101, 27-39.

Oriol-Cotterill, A., Valeix, M., Frank, L.G., Riginos, C. \& Macdonald, D.W. (2015b) Landscapes of coexistence for terrestrial carnivores: the ecological consequences of being downgraded from ultimate to penultimate predator by humans. Oikos, 124, 1263-1273.

R Development Core Team (2016) R: A Language and Environment for Statistical Computing. R Foundation for Statistical Computing, Vienna, Austria.

Rabinowitz, A., Schaller, G.B. \& UGA, U. (1995) A survey to assess the status of Sumatran rhinoceros and other large mammal species in Tamanthi Wildlife Sanctuary, Myanmar. Oryx, 29, 123-128.

Ramesh, T., Sridharan, N., Sankar, K., Qureshi, Q., Selvan, K. M., GokUla K Kannan, N. et al. (2012) Status of large carnivores and their prey in tropical rainforests of South-western Ghats, India. Tropical Ecology, 53, 137-148.

Roy, M., QuReshi, Q., NAha, D., SANKar, K., Gopal, R. \& Jhala, Y. V. (2016) Demystifying the Sundarban tiger: novel application of conventional population estimation methods in a unique ecosystem Population Ecology, 58, 81-89.

Selvan, K.M., Lyngdoh, S., Habib, B. \& Gopi, G.V. (2014) Population density and abundance of sympatric large carnivores in the lowland tropical evergreen forest of Indian Eastern Himalayas. Mammalian Biology - Zeitschrift für Säugetierkunde, 79, 254-258.

Singh, P. \& Macdonald, D.W.M. (2017) Populations and activity patterns of clouded leopards and marbled cats in Dampa Tiger Reserve, India. Journal of Mammalogy, https://doi.org/10.1093/ jmammal/gyx104.

Singh, R., Chauhan, D.S., Mishra, S., Krausman, P.R. \& Goyal, S.P. (2014a) Tiger density in a tropical lowland forest in the Eastern Himalayan Mountains. SpringerPlus, 3, 462.

Singh, R., Qureshi, Q., SAnkar, K., Krausman, P.R. \& Goyal, S.P. (2014b) Evaluating heterogeneity of sex-specific capture probability and precision in camera-trap population estimates of tigers. Wildlife Society Bulletin, 38, 791-796.

Sollmann, R., Linkie, M., HaidiR, I.A. \& Macdonald, D.W. (2014) Bringing clarity to the clouded leopard Neofelis diardi: first density estimates from Sumatra. Oryx, 48, 536-539.

Sunarto, S., Kelly, M.J., Parakkasi, K. \& Hutajulu, M.B. (2015) Cat coexistence in central Sumatra: ecological characteristics, spatial and temporal overlap, and implications for management. Journal of Zoology, 296, 104-115.

Sunquist, M. \& Sunquist, F. (2002) Wild Cats of the World. University of Chicago Press, Chicago, USA.

ThapA, K. \& Kelly, M.J. (2017) Density and carrying capacity in the forgotten tigerland: tigers in the understudied Nepalese Churia. Integrative Zoology, 12, 211-227.

Wilting, A., Mohamed, A., Ambu, L.N., Lagan, P., Mannan, S., Hofer, H. \& Sollmann, R. (2012) Density of the Vulnerable Sunda clouded leopard Neofelis diardi in two commercial forest reserves in Sabah, Malaysian Borneo. Oryx, 46, 423-426.

Xiao, W., Feng, L., Mou, P., Miquelle, D.G., Hebblewhite, M., GoldBerG, J.F. et al. (2016) Estimating abundance and density of Amur tigers along the Sino-Russian border. Integrative Zoology, 11, 322-332.

Zaw, T., Myint, T., Htun, S., Po, S.H.T., Latt, K.T., Maung, M. \& Lynam, A.J. (2014) Status and distribution of smaller cats in Myanmar. Cat News, 8, 24-30.

\section{Biographical sketches}

HLA NAING is field coordinator of WildCRU's clouded leopard programme in Myanmar. JoAnNA Ross's research focuses on the conservation of members of the Bornean felid guild, and their spatial ecology. DAWN BURNHAM is a member of WildCRU's conservation geopolitics research group, with a particular focus on conservation ethics. SAW HTUN is WCS's Deputy Country Director in Myanmar. DAVID W. MACDONALD has a background in behavioural ecology, and is running several long-term and wide-ranging conservation programmes with an emphasis on carnivores and interdisciplinarity. 